This is the peer reviewed version of the following article: Al-Shaer H, Zaman M. Credibility of sustainability reports: The contribution of audit committees. Bus Strat Env. 2018;27:973-986., which has been published in final form at https://doi.org/10.1002/bse.2046. This article may be used for non-commercial purposes in accordance with Wiley Terms and Conditions for Use of Self-Archived Versions.

\title{
CREDIBILITY OF SUSTAINABILITY REPORTS: THE CONTRIBUTION OF AUDIT COMMITTEES
}

\author{
Habiba Al-Shaer \\ Newcastle University \\ Business School \\ 5 Barrack Road \\ Newcastle upon Tyne, NE1 4SE, UK. \\ Email: habiba.al-shaer@ncl.ac.uk
}

\author{
Mahbub Zaman* \\ Hull University \\ Business School \\ Cottingham Road \\ Hull, HU6 7RX, UK. \\ Email: $\underline{\text { m.zaman@hull.ac.uk }}$
}

Forthcoming in 2018 in Business Strategy and the Environment

[This is the accepted, uncorrected version of the paper]

*Corresponding author:

Professor Mahbub Zaman, Hull University, Business School, Cottingham Road, Hull, HU6 7RX, UK. Email: m.zaman@hull.ac.uk

\section{Acknowledgements:}

The authors gratefully acknowledge the constructive comments and suggestions of the editor and anonymous reviewers. We also appreciate the comments and feedback on earlier versions of the paper received from participants at the European Accounting Association Annual Congress (Valencia), National Auditing and Assurance Conference (Oxford) and seminar participants at IE Business School (Madrid) and Auckland University of Technology, New Zealand.

Hot to cite:

Al-Shaer, H. \& Zaman, M. (2018), Credibility of Sustainability Reports: The Contribution of Audit Committees, Business Strategy and the Environment, forthcoming. 


\title{
CREDIBILITY OF SUSTAINABILITY REPORTS: THE CONTRIBUTION OF AUDIT COMMITTEES
}

\begin{abstract}
Concerns about the credibility of sustainability reports can be mitigated through assurance. Although audit committee remit encompasses monitoring of sustainability issues, there are potential complementary and substitution between governance mechanisms. This paper explores the relationship between audit committees and sustainability reporting assurance using resource dependency theory. We find audit committee characteristics have an impact, additional to that of the board of directors and the existence of sustainability committees, on voluntary sustainability assurance. Our results also show that audit committee independence is associated with use of a Big 4 audit firm for sustainability assurance. A negative association between sustainability committees and assurance however indicates assurance could be a burden for small firms. Overall, the findings suggest audit committees add credibility and help improve sustainability reporting through their independence, expertise, and oversight.
\end{abstract}

Keywords: assurance; audit committees; corporate governance; sustainability, resource dependency theory. 


\section{INTRODUCTION}

Boards of directors and management are under pressure from stakeholders to demonstrate their companies are operating in a sustainable way and to incorporate sustainable business practices and sustainable development into their corporate identity (Amran et al., 2014; Dutta et al., 2012; Jizi, 2017)). Commitment to sustainable development and sustainability reporting, which affects corporate transparency and accountability, is thus high on the corporate agenda. In developing sustainability strategies companies need to choose from a range of alternatives and allocate resources, such as human capital and reputation, to different types of sustainability initiatives to develop competitive advantages (Yadav et al., 2016; Arena et al., 2018). As companies become cognizant of the reputational and financial risk associated with sustainability issues (Darnall et al., 2009; Simnett et al., 2009a; 2009b; De Villiers et al., 2011; Moroney et al., 2012; GRI, 2013; KPMG, 2014; Birkey et al., 2016) they are making oversight of sustainability practices and reporting a key priority and widening the remit of those charged with corporate governance ${ }^{1}$ to address stakeholder expectations. To alleviate concerns and add credibility to sustainability reports, companies may voluntarily adopt sustainability reporting assurance (hereafter SRA). ${ }^{2}$

Audit committees, which are now almost universal feature of corporate govenance, are expected to exercise greater oversight over both financial and non-financial information in assessing company performance (ICAA, 2014; EY, 2014; Trotman and Trotman, 2015). Audit committees are increasingly concerned about not misleading stakeholders and ensuring the quality and reliability of both financial and non-financial information released to the market. ${ }^{3}$

\footnotetext{
1 This typically means the boards of directors but, depending on country specific regulatory context, can also include subcommittees, such as audit committees and sustainability committees.

2 SRA has similarities with the statutory financial audit. Cohen and Simnett (2015: 66) note: "The main assurance standard used for assuring CSR reports, ISAE3000 (IAASB, 2013), parallels the financial statement audit approach, and involves (1) gaining and understanding of the entity, (2) undertaking a risk assessment (at the assertion level if appropriate), and then (3) responding to assessed risks by employing the most efficient and effective combination of tests of control and substantive testing".

3 See for example Carcello et al. (2011); Zaman et al. (2011); Salleh and Stewart (2012); and FRC (2015).
} 
Indeed, Trotman and Trotman (2015) find audit committees are concerned about sustainability reporting and its accuracy and increasingly monitor the reporting process. Similarly, FERMA (2014) reports that sustainability is a key subject for coordination between management, the 'support functions' and the board and its audit committee as well as the external stakeholders of the business.

The existence of boards of directors, audit committees and sustainability committees in companies raises interesting questions. Do audit committees have an incremental contribution in enhancing the credibility of sustainability reports when a company has boards with independent directors and a board level sustainability committee? Additionally, does the incremental contribution of audit committees vary between large versus small companies? Our paper addresses these two questions recognising that governance structures may complement or substitute for each other and that here is relatively little research on these relations (Armstrong et al., 2010; Cohen and Simnett, 2015; Farooq and de Villiers, 2017.)

This paper provides evidence on the contribution of audit committees, incremental to that of the boards of directors and the existence of sustainability committees, on SRA and contributes to the literature in a few ways. First, while it is generally recognised that corporate governance can affect assurance, there is a paucity of research on audit committees and SRA. For example, although Peters and Romi (2015) examine the role of governance mechanisms on the likelihood of SRA in the US, they control for only one dimension of audit committees, i.e. audit committee size, and do not explore the effect of audit committee attributes on SRA nor discuss the incremental contribution of audit committees on SRA, additional to that of the board of directors and sustainability committees. Amran et al. (2014) focus on one corporate governance mechanism, i.e. the role of the board of directors, on sustainability reporting quality ${ }^{4}$ and suggest that future research needs to examine the role of audit committees in this

\footnotetext{
4 Amran et al. (2014) focus on the reliability and validity of sustainability reports as two aspects of the quality and suggest that remaining aspects such as credibility and comprehensiveness need to be investigated.
} 
respect. Relating to their call, our paper focuses on audit committee contribution in enhancing the credibility of sustainability reports through voluntary assurance. To the best of our knowledge, this is the first UK paper to focus on the incremental role of audit committees on SRA when a company has boards with independent directors and a board level sustainability committee, and provide evidence on the association between audit committees and SRA.

Second, most studies on SRA are either based on cross-country or US data. Crosscountry studies tend to cover a sample period and include years during which sustainability reporting is at an evolutionary stage of development (e.g. Simnett et al., 2009a; Perego and Kolk, 2012; Green and Zhou, 2013; Clarkson et al., 2015a; 2015b). Institutional differences however can affect sustainability reporting (Young and Marais, 2012; Birkey et al, 2016). ${ }^{5}$ For instance, the litigious nature of the US environment means US companies are likely to be exposed to greater litigation risk and uncertainties about the benefits of SRA. Our paper extends the literature and provides recent evidence from the less litigious environment of the UK on the association between audit committees and SRA. In the UK the Companies Act requires boards of directors to have regard to community and environmental issues when considering their duty to promote success of the company and directors' assessment of risk is expected to include health, safety and environmental reputation and business probity issues. Unlike statutory audit of financial statements in the UK, the statutory auditor is not required to verify environmental information (DEFRA, 2013). Also, the UK adopts a non-mandatory approach to corporate governance and there is a greater history of audit committees and their expected role has over time expanded beyond a focus on the financial aspects of corporate governance to oversight of risk and non-financial reporting. Third, our paper adds to qualitative studies by providing evidence on the association between audit committees and

\footnotetext{
5 The adoption of SRA over a period, especially in cross-country studies, is subject to institutional and regulatory settings. This also applies to audit committees - they have evolved over time and their functioning and impact is subject to organizational as well as institutional settings. See for example Beasley (1996); Collier and Zaman (2005); Turley and Zaman (2007); Cohen et al. (2010); Salleh and Stewart (2012); Beattie et al. (2014).
} 
SRA. It complements studies such as O'Dwyer's (2011) examination of the construction of sustainability assurance based on interviews with practitioners from two Big Four audit firms and Trotman and Trotman's (2015) study based on interviews with audit committee members, senior accountants and internal auditors in Australia on the role of internal auditors on sustainability reporting.

Overall, we provide evidence on the association between audit committees and SRA. Consistent with calls for audit committees to take on a wider remit, we find audit committees have a positive and significant association with SRA. This effect is incremental to that of the boards of directors and the existence of sustainability committees. Audit committee contribution on SRA holds in large and small firms subsamples and after controlling for industry effects. The existence of sustainability committees, however, has a negative impact on SRA in small firms. The results suggest that rather than substituting for corporate governance mechanisms audit committees perform a complementary role and their monitoring extends beyond financial reporting to oversight of sustainability issues.

The remainder of the paper is structured as follows. The next section reviews the literature, provides the theoretical framework, and outlines our hypothesis. Section 3 sets out the research study in terms of sample, data and model. In section 4 we report the empirical results and in section 5 we provide a summary and draw conclusions.

\section{PRIOR LITERATURE AND HYPOTHESIS DEVELOPMENT}

\subsection{Credibility of sustainability reports}

To alleviate stakeholder and regulatory concerns companies are increasingly reporting on sustainability issues and having the reports voluntarily assured. Research on the credibility of sustainability reports is at a nascent stage. ${ }^{6}$ Perego and Kolk (2012) provide descriptive

\footnotetext{
${ }^{6}$ The limited but evolving research relating to SRA may be categorised into: cross-country studies focused on global developments and adoption, including standard setting and policy formulation (Simnett et al., 2009a; Mock et al.,
} 
evidence on patterns of SRA adoption across countries by multinational companies during 1999-2008 and find significant variation in adoption. This is not surprising given the evolutionary nature of sustainability reporting and variation in country level institutional pressures for their adoption. In contrast to Perego and Kolk's (2012) descriptive study, Simnett et al. (2009a) examine firms from 31 countries that published sustainability reports during 2002-2004 and find SRA is a function of company-, industry-, and country-related factors. Their study does not consider the association between audit committees and SRA. This is also the case with Ruhnke and Gabriel (2013). Their investigation of the largest companies from the UK, Germany and Netherlands does not extend to considering the effect of corporate governance on sustainability reporting. In a cross-country study covering 26 countries for the period 2003-2008 Clarkson et al. (2015b) find that SRA increases the likelihood of firms being included in the Dow Jones Sustainability Index and helps in attracting socially responsible investors. Like other cross-country studies, they also do not focus on the role of governance, especially of audit committee characteristics, on SRA.

In a recent study based on interviews with audit committee members, senior accountants and internal auditors in Australia, Trotman and Trotman (2015) find audit committees are concerned about sustainability related processes and the accuracy of sustainability reports. Junior et al. (2014) report that voluntary assurance can enhance the credibility of sustainability reports. However, there are different standards for SRA in the UK and the assurance provider may be a Big Four firm, an accounting firm, a non-accounting firm or a specialist consultant. Assurance providers thus can vary in their background and expertise (Smith et al., 2011; Perego and Kolk, 2012) and the plurality of guidance on SRA is

2013); experimental and capital market studies tending to focus on investor perceptions and value relevance of sustainability reporting and assurance (Clarkson et al., 2015b; Moroney and Trotman, 2016); qualitative studies examining SRA within particular organizational settings including the role of practitioners, management and boards of directors and audit committees in the SRA process (Jones and Solomon, 2010; O'Dwyer, 2011; O'Dwyer et al., 2011; Trotman and Trotman, 2015). 
compounded by the fact that assurance providers can use aspects of the various standards on an ad hoc 'pick and mix' basis (CorporateRegister.com, 2008, p. 13; see also Smith et al., 2011). ${ }^{7}$

\subsection{Resource dependency theory}

The current study is premised on a theoretical framework based on resource dependency theory (RDT) to identify factors that drive an organisation to acquire assurance for sustainability reports. Boards of directors play two distinct roles: monitoring role which has been mainly examined following agency theory (Jensen and Mackling, 1979) and service role which is the perspective adopted in the RDT to explain the role of the board and its committees in achieving sustainability objectives (see for example Hillman and Dalziel, 2003; Mallin and Michelon, 2011; Ben-Amar and Mcllkenny, 2015; Shaukat et al., 2016; Helfaya and Moussa, 2017; Jizi, 2017). The service role refers to the ability of the board to bring resources to the firm through human capital (experience, expertise, knowledge, and reputation) and relational capital (network of ties) (Hillman and Dalziel, 2003). RDT indicates that board-level human vision and strategies are resources in the firm that could be used to create sustainable competitive advantages (Hillman et al., 2009; Shaukat et al., 2016; Helfaya and Moussa, 2017). Moreover, the composition of the board and its committees could be seen as a unique governance mechanism which helps firms to improve their reporting practice and hence their sustainable performance (Jizi, 2017).

\footnotetext{
7 There are two frameworks for assurance services. Under AA1000AS assurance is "an engagement in which an assurance provider evaluates and expresses a conclusion on an organization's public disclosure about its performance as well as underlying systems, data and processes against suitable criteria and standards in order to increase the credibility of the information for the intended audience" (AccountAbility, 2008). The other standard, international standard of assurance engagement ISAE3000 provides more technical explanation in its definition (Junior et al., 2014) and notes an assurance is "an engagement in which a practitioner aims to obtain sufficient appropriate evidence in order to express a conclusion designed to enhance the degree of confidence of the intended users other than the responsible party about the outcome of the measurement or evaluation of an underlying subject matter against criteria" (The International Auditing and Assurance Standards Board, 2011, p. 19).
} 
Boards of directors are responsible for setting firms' sustainable agenda and allocating the necessary resources to ensure business sustainability (Jizi, 2017). They also encourage reporting on sustainable development activities to ensure communication with different stakeholders (Xie and Hayase, 2007; Rowe et al., 2014; Ben-Amar and Mcllkenny, 2015). According to Markarian and Parbonetti (2007, p.1225), the board comprises of directors of different expertise and experiences who play distinct roles consistent with their own skills, competence, and expertise. This diversity produces a mosaic of decision making structures and subsequent firm behaviour. Since the board is subject to workload allocation and responsibility distribution having a large board can increase the efficiency in setting sustainability agenda (Jizi, 2017). Independent directors can also help attract vital resources and assist in directing these resources towards improving firm sustainability strategy and sustainability reporting (Helfaya and Moussa, 2017; Jizi, 2017).

According to RDT, the structure of the board and its committees can act as crucial resources to create value and achieve sustainable advantage through providing expertise and advice, enhancing legitimacy and firm's image, developing connections and building external relations with important stakeholders, and facilitating access to resources (Galbreath, 2010; Ortiz-de-Mandojana and Aragon-Correa, 2015; Shaukat et al., 2016; Ben-Amar et al., 2017; Jizi, 2017). Sustainability committees, as part of the corporate governance structure, can be a capital resource providing insightful advice to the management about stakeholder expectations and aid in the developing of sustainable strategies (Mallin and Michelon, 2011; Amran et al., 2014; Shaukat et al., 2016). Also, since sustainability reporting assurance is influenced by the firm's monitoring environment, audit committee contributions could also have a direct effect on firms' sustainability agenda. A well-designed audit committee is likely to be more successful in allocating firm's resources towards acquiring external assurance over sustainability reports. Audit committee members' independence and financial expertise can attract human and relational capital, which in turn can improves firm's sustainability 
reporting (Helfaya and Moussa, 2017). Therefore, from the perspective of RDT, effective audit committees are essential in determining firm's sustainable strategies.

\subsection{Audit committee incremental contribution}

It is widely recognised that boards of directors can affect sustainability reporting and performance (Michelon and Parbonetti, 2012; Post et al., 2011; Zhang et al., 2013; Al-Shaer and Zaman, 2016). ${ }^{8}$ In addition to boards, the existence of sustainability committees, whose functions typically include managing the quality of stakeholder engagement process and of the sustainability reporting policies of the company, may signal greater monitoring of disclosures provided to stakeholders (Michelon and Parbonetti, 2012; Post et al., 2011). Besides the board of directors and the existence of sustainability committees, audit committee characteristics can also affect the credibility of sustainability reports because they are expected to address issues related to controls, risks and sustainability (Bhimani and Soonawalla, 2005; Collier and Zaman, 2005; Salleh and Stewart, 2012; FRC, 2015). Since issues related to sustainability reporting are voluntary with high level of managerial discretion, it is interesting to investigate the incremental contribution of audit committees to the credibility of sustainability reports (Al-Shaer et al., 2017).

Evidence from practice also suggests that sustainability decisions and associated reporting are important to audit committee members and there is a growing expectation that audit committees and auditors will be accountable for overseeing and assuring non-financial

\footnotetext{
8 Over time, and partly in response to concerns about social impact of businesses and accountability to stakeholders, there has been an increasing emphasis on green governance and boards of directors are expected to play greater role in monitoring sustainability performance and reporting (Post et al., 2011). In the UK for instance the Companies Act 2006 requires boards of directors to have regard to community and environmental issues when considering their duty to promote the success of the company. Oversight of sustainability reporting is also implicit in the UK Corporate Governance Code which states that "the board should set the company's values and standards and ensure that its obligations to its shareholders and others are understood and met" (FRC, 2015: A1). Similarly, the Turnbull Report (ICAEW, 1999) also advises directors that risk assessment should not be limited to financial risk but also those related to health, safety and environmental reputation, and business probity issues. Given the emphasis on sustainability reporting and heightened concerns about the social impact of businesses, we expect that boards of directors will have a positive association with SRA.
} 
reporting information due to the evolution of assurance and control of non-financial information. Audit committees, and the boards of directors more broadly, play a role in engaging the assurance provider (ICAA, 2014). For example, surveys of institutional investors show that sustainability reporting is becoming a core area of audit committee oversight. The EY (2014) global survey finds 55.9\% of respondents consider it is essential or important that audit committees have oversight responsibilities of sustainability reporting while $26 \%$ consider it is useful.

\subsection{Hypothesis development}

Although the role of audit committees in relation to SRA has not been the subject of much research, extant evidence on audit committees suggest they are likely to be associated with SRA. Audit committees have been found to be associated with improved financial reporting and auditing outcomes. ${ }^{9}$ Audit committees may find SRA provides them reassurance that sustainability reporting matters are being managed. They may also perceive that SRA helps to protect their reputation. Consequently, they may choose to signal their greater oversight over sustainability reporting and prefer to have these reports externally assured. Audit committees could provide additional oversight of climate change, sustainability, and energy conservation issues, incorporating them into enterprise wide risk assessment, enhancing disclosure quality, evaluating the reporting system, and providing assurance of such information (EY, 2010). The qualitative features of audit committees, in terms of qualification, expertise and diligence can act as resources which are likely to affect their oversight of sustainability reporting.

\footnotetext{
9 These include earning quality (Pomeroy and Thornton, 2008), internal control (Zhang et al., 2007; Goh, 2009; Sarens et al., 2013; Abbott et al., 2015; Mat Zain et al., 2015), and reduction in financial reporting fraud (Beasley, 1996; Beasley et al., 2009; Cohen et al., 2004) and greater oversight of external and internal auditing (e.g. Turley and Zaman, 2007; Bedard and Gendron, 2010; Carcello et al., 2011; Zaman and Sarens, 2013; Martinov-Bennie et al., 2015; Trotman and Trotman, 2015).
} 
Key audit committee characteristics generally regarded as important for exerting influence within companies and affecting outcomes include expertise, independence, diligence and size (Turley and Zaman, 2004; Bedard and Gendron, 2010). The expertise of audit committee members is likely to influence the extent of monitoring provided over sustainability related issues. Audit committee expertise enhances earnings quality (Abbott et al., 2004; Cohen et al., 2004; Beasley et al., 2009; Bedard and Gendron, 2010; Erkens and Bonner, 2012). ${ }^{10}$ The UK Corporate Governance Code recommends that audit committees include members with financial literacy and at least one member is a financial expert (FRC, 2015). We expect a positive association between audit committee expertise and SRA.

When audit committees are composed of independent non-executive directors they are more likely to be able to exercise more power over management in requiring more informative and reliable disclosures (Abbott et al., 2004; Turley and Zaman, 2004; Pomeroy and Thornton, 2008; Carcello et al., 2011; Al-Shaer et al., 2017). Lack of audit committee independence can impede good corporate governance and may lead to insufficient performance due to the fact that such committee will not effectively question the outcome of the audit (Klein, 2002; Al-Najjar, 2011). Also, independent audit committees are expected to be able to evaluate objectively internal control and reporting practices, and to question management's actions and policies when necessary (Abbott et al., 2004). We thus expect audit committee independence will have a positive association with SRA.

Previous research has established the importance of active committees for the oversight of the financial reporting process. Meeting frequency has been associated with higher quality reporting and monitoring (Beasley et al., 2009; Zaman et al., 2011) ${ }^{11}$. Audit

\footnotetext{
10 For instance, Abbott et al. (2004) find a negative association between audit committee financial expertise and accounting restatements. Zhang et al. (2007) also report a negative association between expertise and material weaknesses.

${ }^{11}$ We recognise that activeness is not the same as diligence. The latter however cannot be easily measured using publicly available information and thus, consistent with the audit committee literature, we use the number of audit committee meetings as an indicator of audit committee activity. Archival studies are not best suited for capturing the subjectivities of diligence. Qualitative research approaches are more likely to be fruitful for such an endeavour.
} 
committees with three or more members receive more legitimacy and authority and exert greater influence over the top management team in monitoring (Abbott et al., 2004). The UK Corporate Governance Code recommends that audit committees have at least three members (FRC, 2015) as larger audit committees are likely to represent wider interests and member contribution to monitoring and improving disclosures. ${ }^{12}$ We expect active audit committees are likely to have a positive association with SRA.

Although companies may have a sustainability committee, as a subcommittee of the board of directors, there may be significant management representation on it. Therefore, the existence of internal monitoring mechanisms provided by firm's core governance structure including the existence of independent board members and audit committees, is likely to affect voluntary SRA. In examining SRA, we view reporting on sustainability and the oversight of risk and corporate governance as being intertwined and inextricably interdependent. There are multiple stakeholders with individual risk profiles who can shift some of the cost of monitoring to other stakeholders (Knechel and Willekens, 2006: 1344). This can affect the incremental contribution of ACs in enhancing the credibility of sustainability reports. Audit committee members and independent board members face risks which are different from that of management and to demonstrate their oversight of risks and reporting and to protect their reputation against questionable reporting decisions made by management they may require more monitoring (Hay et al., 2008; Zaman et al., 2011). Consequently, rather than governance mechanisms substituting for one another, there could be an overall increase in investment in monitoring (Cohen et al., 2004; Knechel and Willekens, 2006; Hay et al., 2008; Chan et al., 2014).

Overall, prior research and policy promulgations suggest audit committees are likely to be concerned about sustainability related processes and the accuracy of sustainability reporting and auditing (e.g. Mangena and Pike, 2005; Li et al., 2012). 
reports. Given the increasing expectations of audit committees and concerns about the reliability of (non-financial) reporting and the widening of audit committee remit, we expect audit committees (i.e. independent, expert, active and large sized) to have a positive association, additional to that of boards of directors and the existence of sustainability committees, with SRA. Our hypothesis is thus:

H1: Audit committees have an incremental contribution, i.e. additional to that of the boards of directors and the existence of sustainability committees, on sustainability reporting assurance.

\section{RESEARCH DESIGN}

\subsection{Regression models}

To test the contribution of ACs on SRA that is incremental to board of directors and when sustainability committees exist we use the following model.

$\mathrm{SRA}=\alpha+\beta_{1} \mathrm{ACSIZE}+\beta_{2} \mathrm{ACIND}+\beta_{3} \mathrm{ACEXP}+\beta_{4} \mathrm{ACMEET}+\beta_{5} \mathrm{SUSCOM}+\beta_{6} \mathrm{BODSIZE}$ $+\beta_{7} \mathrm{BODIND}+\beta_{8} \mathrm{BODMEET}+\beta_{9} \mathrm{SIZE}+\beta_{10} \mathrm{LEV}+\beta_{11} \mathrm{ROA}+\beta_{12} \mathrm{IND}+\varepsilon_{\mathrm{it}}$

where:

$S R A=\quad$ if sustainability report is externally assured $=1,0$ otherwise $A C S I Z E=$ number of audit committee members

$A C I N D=$ proportion of audit committee members who are independent

$A C E X P=$ proportion of audit committee members with financial expertise

$A C M E E T=$ number of audit committee meetings held during the year

SUSCOM $=$ if a sustainability committee exists $=1$, otherwise 0

$B O D S I Z E=$ number of directors on the board

$B O D I N D=$ proportion of independent directors on the board

$B O D M E E T=$ number of board meetings held during the year

$S I Z E=$ natural log of total assets

$R O A=$ return on asset

$L E V=$ total debt to total asset

$I N D=\quad$ industry dummy variable

$\varepsilon=$ error term

\subsection{Data and variables}

We examine the contribution of audit committees to the credibility of sustainability reporting using a sample of companies listed on the London Stock Exchange. Consistent with our research question on the incremental contribution of audit committees, additional to that of 
board of directors and the existence of sustainability committees, in examining SRA we include audit committee characteristics as well variables relating to boards of directors and the existence of sustainability committees. Our dependent variable reflects the propensity of sustainability reporting assurance (SRA) measured using a dummy variable equal to 1 if sustainability reports are externally assured and 0 otherwise. Audit committee characteristics in our model include number of audit committee members (ACSIZE), proportion of audit committee members who are independent directors (ACIND), proportion of audit committee members with financial expertise (ACEXP) and number of audit committee meetings held during the year (ACMEET). We use SUSCOM a dummy variable equal to 1 if a sustainability committee exists and 0 otherwise. ${ }^{13}$

Following the literature, we include board size (BODSIZE) measured by total number of directors serving on the board. Larger boards tend to have members from diverse backgrounds and experiences and may reflect greater commitment to strategic activities (Lim et al., 2007; De Villiers et al., 2011). Boards with greater proportion of independent directors may provide more monitoring over management to build corporate reputation and trust (Beasley, 1996). We define board independence (BODIND) as the proportion of independent directors to the total number of directors on the board. One of the main duties of the board is to hold meetings that enable oversight of financial information and increase the effectiveness of board decisions and improve transparency and quality of disclosures (Carcello et al., 2011). We control for board activity using the total number of board meetings held during the year (BODMEET). ${ }^{14}$

\footnotetext{
13 We identified the existence of SUSCOM through a review of sustainability and/or annual report. Companies vary in the specific title they assign to the board subcommittee dealing with sustainability issues, e.g. environmental committee, corporate social responsibility committee. We took this variation in the label into consideration in our coding.

14 Unlike in the US, CEO duality is increasingly rare in the UK. We considered including CEO duality in our model but dropped it due to lack of statistical variation across firms.
} 
Prior literature suggests that it is important to control for firm characteristics when examining sustainability reporting (see Simnett et al., 2009a; Rodrigue et al., 2013). We include firm size (SIZE) measured by the natural log of total assets, leverage (LEV) measured by total debt to total asset ratio, profitability of the firm measured by return on asset (ROA), and industry classification (IND) using the DataStream Industry Classification Benchmark (ICB) level 1 industries (ten groups).

Our initial sample includes all the companies listed in 2012 in the UK FTSE350. Elimination of firms with missing data reduces the sample size to 333 firms. The Global Reporting Initiative database is the main source for our dependent variable. We supplemented this with information from the 2012 annual reports of the sample firms. For corporate governance data we relied on the 2012 annual reports and obtained financial data from DataStream. For additional analysis, we divide our sample into subsample groups based on industry (non-financial industry and sustainability sensitive industries) and size (large vs. small) for sensitivity testing.

\section{RESULTS AND ANALYSIS}

\subsection{Descriptive statistics}

Table 1 reports descriptive statistics for key variables in our model. Panel A shows the means for all firms, whereas Panel B shows the means by industry. In Panel C we report the means for firms with and without SRA and for firms with and without a sustainability committee. We also report the t-test for differences in the means between the two subsamples. Panel A shows that the mean for our dependent variable SRA is 0.174 . With regards to audit committee variables, we find the mean audit committee size (ACSIZE) is 3.922 indicating that audit committees in our sample firms have on average four members. The mean for audit committee independence (ACIND) is 0.781 and indicates compliance with the UK Corporate Governance Code (FRC, 2015) is high. The mean for audit committee expertise (ACEXP) is 0.258 and the 
mean for audit committee meetings (ACMEET) is 4.158 and indicates that audit committees in our sample meet on average four times a year. SUSCOM has a mean of 0.360 and suggests that over a third of our sample firms have a separate sustainability committee.

We find the mean board size (BODSIZE) is 9.336 and board independence (BODIND) is 0.51 which means that half of the board members are independent. The mean number of board meetings is 8.187 . Regarding firm-specific control variables, we find the mean firm size (SIZE) is $£ 1,149,379,000$, return on assets (ROA) is 0.079 and leverage (LEV) is 0.189 . When we consider the means for the variables in our models based on industry (Panel B) we find that the basic materials industry has the highest mean for SRA (i.e. 0.48) indicating almost half the companies in this sector have their sustainability report externally assured. We also find that the consumer goods industry has the highest mean of 0.571 for SUSCOM, i.e. existence of a sustainability committee, whereas the financials industry has the lowest SUSCOM mean of 0.21 and the lowest SRA mean of 0.09 .

In Panel $C$ we report the means and $t$-tests for companies that have SRA and those that do not $(\mathrm{SRA}=1 / 0)$ and for firms with a sustainability committee and those without (SUSCOM=1/0). We find in the subsample of firms that have their sustainability reports externally assured, audit committees are larger, more independent, have more financial experts, and are more active. The boards of directors of assured firms, i.e. those with SRA, are also larger, more active and more independent compared to those without SRA. Compared to firms that do not have a sustainability committee, we find the subsample of firms with SUSCOM have audit committees that are more independent and more active and have more financial experts. The boards of directors of firms with sustainability committees are also larger and more active compared with firms that do not have a sustainability committee.

[Table 1 about here] 
Table 2 shows the correlation matrix for variables used in our analysis. We find that SRA has a significant and positive association with ACMEET, BODSIZE and LEV. SUSCOM is significant and positively associated with ACEXP, ACMEET, BODSIZE, BODMEET and LEV. 15

\section{[Table 2 about here]}

\subsection{Multivariate results}

Consistent with our earlier discussion on the association between audit committee and SRA we report the findings of our regression tests in this section. Sustainability reporting assurance (SRA) is a dichotomous variable and thus we use logistic regression. Table 3 tests the effect of audit committee on SRA. Model 3.1 tests the impact of board characteristics, the presence of sustainability committees and firm-specific control variables on SRA, and Model 3.2 tests the contribution of audit committee, incremental to that of the board of directors and the existence of sustainability committee. Model 3.2 shows that both audit committee independence (ACIND) and audit committee expertise (ACEXP) have a positive and significant association with SRA ( $\mathrm{p}<0.01)$. Also, audit committee meeting (ACMEET) has a positive and significant association at $\mathrm{p}<0.05$ with SRA. Audit committee size is also positive though not significant. We find the presence of sustainability committee (SUSCOM) has a negative and significant impact on SRA at $\mathrm{p}<0.10$ (Model 3.1) and $\mathrm{p}<0.01$ (Model 3.2). Additionally, board size (BODSIZE) has a positive and significant association at $\mathrm{p}<0.01$ with SRA (Models 3.1 and 3.2). Of firm-specific control variables, we find leverage (LEV) has a significant and positive association at $\mathrm{p}<0.01$ with SRA (Model 3.1 and 3.2) and suggests that leveraged firms are more

15 We do not find any correlation above 0.5 among the variables which suggests multicollinearity is not an issue. 
likely to have their sustainability reports externally assured. The inclusion of audit committee variables in Model 3.2 also improves the model fit (Pseudo $\mathrm{R}^{2}$ improves from 0.147 to 0.225 ).

Overall, our findings provide support for our hypothesis that audit committees have a contribution incremental to that of the boards of directors and sustainability committees on SRA consistent with the RDT argument that through providing expertise, advice, and vigilance board committees can act as crucial resources for creating value and achieving sustainable advantage (Galbreath, 2010; Ortiz-de-Mandojana and Aragon-Correa, 2015; Shaukat et al., 2016). Our results show that in the UK where the current SRA practice has been criticised as lacking credibility and having different standards and assurance providers, and concerns have been expressed about the degree of managerial control, it appears that the qualitative characteristics of audit committees, i.e. expertise, independence, and meetings, affect the voluntary assurance of sustainability reporting.

From a RDT perspective, the demand for assurance may place an increased drain on resource use when there is insufficient market for resources. This is more likely to pertain to small firms and explain the negative impact of SUSCOM on SRA we observed earlier. To explore this further, we split our sample into small and large firms based on median size (Models 3.3 and 3.4 respectively). We find in large firms audit committee independence and meetings have a positive and significant association with SRA at $\mathrm{p}<0.05$ and audit committee expertise is positive and significant at $\mathrm{p}<0.10$ with SRA (Model 3.4). Additionally, in large firms SUSCOM is not significant but it has a positive association with SRA. In small firms (Model 3.3) we find ACIND and ACMEET have a positive and significant association at $p<0.05$ with SRA but SUSCOM has a negative and significant association at $p<0.01$. It may be the case that sustainability committees are sufficient for providing oversight of sustainability reporting in small firms and hence the negative association between SUSCOM and SRA. 
Additionally, small firms may perceive that the incremental cost of external assurance outweighs the benefit. ${ }^{16}$

\section{[Table 3 about here]}

To further explore the incremental effect of ACs, in Table 4 we introduce interaction variables by combining SUSCOM with each audit committee variable. Model 4.1 uses the full sample, Model 4.2 uses small firms extracted from the full sample whereas Model 4.3 is based on large firms. Our results show that the interactions of SUSCOM with ACIND is positive and significant at $\mathrm{p}<0.05$ for the full sample and for small firms, and the interaction of ACEXP and SUSCOM is positive and significant at $\mathrm{p}<0.10$ for the full sample and at $\mathrm{p}<0.05$ for small firms subsample. ${ }^{17}$ The individual impact of SUSCOM in the model remains negative and significant for the full sample and for small firms subsample and positive and insignificant for large firms subsample. Consistent with our previous findings, the individual impact of ACIND and ACMEET remains positive and significant for the full sample and both the large and small firms subsamples. ${ }^{18}$ Overall, after we include board of directors and sustainability committee existence in the regression test, we find a positive and significant impact of audit committee variables (independence, expertise, and meeting) on SRA which indicates ACs have an incremental contribution and add credibility to sustainability reports.

[Table 4 about here]

\footnotetext{
16 Jones and Solomon (2010) note from interview evidence that small firms may consider internal assurance provided by sustainability committees is sufficient.

17 The model we use to test this is: SRA $=\alpha+\beta_{1} \mathrm{ACSIZE}+\beta_{2} \mathrm{ACIND}+\beta_{3} \mathrm{ACEXP}+\beta_{4} \mathrm{ACMEET}+\beta_{5} \mathrm{SUSCOM}$ $+\beta_{6} \mathrm{SUSCOM}^{*} \mathrm{ACSIZE}+\beta_{7} \mathrm{SUSCOM}{ }^{*} \mathrm{ACIND}+\beta_{8} \mathrm{SUSCOM} * \mathrm{ACEXP}+\beta_{9} \mathrm{SUSCOM} * \mathrm{ACMEET}+\beta_{10} \mathrm{BODSIZE}+\beta_{11} \mathrm{BODI}$ $\mathrm{ND}+\beta_{12} \mathrm{BODMEET}+\beta_{13} \mathrm{SIZE}+\beta_{14} \mathrm{LEV}+\beta_{15} \mathrm{ROA}+\beta_{16} \mathrm{IND}+\varepsilon_{\mathrm{it}}$

18 We acknowledge that high correlation among interaction term and its two components is inevitable. To reduce the VIF values, we subtract the mean from continuous components (mean centering) before creating the product variable. Please refer to the Stata discussion forums for further insight.
} 


\subsection{Additional analysis: industry effects}

We further explore industry influence on the impact of ACs on SRA by testing both nonfinancial firms sample and sustainability-sensitive industry firms sample. Firms in the financial industry exhibit distinct corporate governance and financial characteristics. Since these firms make up almost one third of our sample, in Table 5 we provide results of additional analysis for non-financial firms. We follow our previous approach and first examine the effect of boards of directors and the existence of sustainability committees and other controls (Model 5.1) and then we add audit committee variables in Model 5.2 to examine if audit committees have an incremental contribution, additional to that of the boards and SUSCOM, on SRA for firms from the non-financial industry. Our result shows that ACIND is positive and significant at $\mathrm{p}<0.05$, ACMEET and BODSIZE are positive and significant at $\mathrm{p}<0.01$ while SUSCOM is negative and significant at $\mathrm{p}<0.01$ with SRA. This is consistent with our previous findings in terms of significance and the direction of associations. The Pseudo $\mathrm{R}^{2}$ increases from 0.135 in Model 5.1 to 0.222 when we add audit committee variables in Model 5.2 .

[Table 5 about here]

We also provide an additional analysis for sustainability sensitive industries. We include industry as a categorical variable following Sierra et al. (2013) and assign a value of 0-5 based on firms' sustainability-sensitive activities. We assign a value of 0 if the company belongs to financial services industry, a value of 1 if the company belongs to technology and telecommunication industry, a value of 2 if the company belongs to consumer services and health care industry, a value of 3 if the company belongs to consumer goods industry, a value of 4 if the company belongs to basic materials, utilities and construction industry, and a value 
of 5 if the company belongs to oil and gas industry. ${ }^{19}$ Our findings in Models 5.3 and 5.4 are consistent with our previous findings in Models 5.1 and 5.2 and show that ACIND, ACMEET, and BODSIZE have a positive and significant association SRA while SUSCOM has a negative and significant association with SRA. Overall, the results in Table 5 are consistent with the view that audit committees have an incremental contribution on SRA and support the premise of RDT that effective audit committees can act as a vital resource in determining a firm's sustainability strategy. ${ }^{20}$

\subsection{Additional analysis: assurer and standard choice}

As an additional test we provide exploratory evidence on the association between AC contribution and both SRA type and choice of SRA standard. Prior literature argues that assurance service is perceived to be of a higher quality when the provider is a top tier accountancy firm (Junior et al., 2014; Cheng et al., 2012; Hodge et al., 2009; Farooq and de Villiers, 2017). We extract the sample of companies that have their sustainability reports assured and investigate the assurer type and assurance standard applied in SRA. For assurance type (SRAType) we use a coding scale based on the type of the external assurer. Prior research suggests that assurance provider type can affect investor perceptions (Pflugrath et al., 2011; Green and Taylor, 2013; Ferguson and Pundrich, 2015). We assign a score of 1 if sustainability reports are externally assured by a non-accounting firm, 2 if the report is

\footnotetext{
19 We have 18 companies out of 333 (5.37\%) belong to Oil and Gas; 102 companies out of 333 (30.45\%) belong to Basic Materials, Utilities, and Construction; 24 companies (7.16) out of 333 belong to Consumer Goods; 65 companies (19.4\%) out of 333 belong to Consumer Services and Health Care; 24 companies (7.16\%) out of 333 belong to Technology and Telecommunication; and 100 companies (30.03\%) out of 333 belong to Financial Services. $20 \mathrm{We}$ also acknowledge that our current regression design does not sufficiently address the potential endogeneity concern where it is likely that both audit committee (and board of directors) characteristics and the decision to acquire external assurance are mutually dependent on unobserved but relevant factors. To mitigate this, we adjust our research design by applying a matching approach which requires finding potential determinants of a firm's decision to acquire external assurance, we chose company size and industry. We investigate the association between audit committees and SRA using a matched-pair sample of SRA and non-SRA firms based on size and industry. Our tests results (untabulated) remain qualitatively similar and show that audit committees have an incremental role, i.e. additional to that of the boards and SUSCOM, on sustainability assurance (SRA).
} 
externally assured by a non-Big Four accounting firm, and 3 if the external assurer is a Big Four firm. ${ }^{21}$

Regarding the choice of assurance standard (SRAStd), AA1000AS and ISAE3000 are the most commonly used standards for providing assurance on sustainability reporting. AA1000AS is a generic standard designed specifically for sustainability assurance whereas ISAE3000 is used on all non-financial assurance engagement (Lansen-Rogers and Oelschlaegel, 2005; Simnett, 2012; Mock et al., 2013). The two approaches are complementary and compatible hence we expect the existence of both will enhance the quality of sustainability reporting assurance (Junior et al., 2014).22 We rely on a coding scale based on the adopted assurance approach and assign a score of 0 if sustainability reports are assured but no assurance standard is specified, 1 if either AA1000AS or ISAE3000 is used, and 2 if both standards are used for SRA. ${ }^{23}$

[Table 6 about here]

Table 6 reports the regression results when we use SRAType as the dependent variable (Models 6.1 and 6.2) and SRAStd as the dependent variable (Models 6.3 and 6.4). The results in Table 6 are based on the reduced sample of firms that have their sustainability reports externally assured. Both for SRAType and SRAStd, which we measure using a coding scale, we use ordered-Probit specification for the regression tests. When we use assurer type (SRAType) as the dependent, our results show that ACIND is positive and significant at $\mathrm{p}<0.01$ (Models 6.2) and BODSIZE is positive and significant at $\mathrm{p}<0.05$ (Model 6.1 and 6.2).

\footnotetext{
${ }^{21}$ We find $9(15 \%)$ companies obtain external assurance from non-accounting firms, 20 (33\%) companies obtain external assurance from non-Big Four accounting firms, and 31 (52\%) companies obtain external assurance from Big Four firms.

22 AccountAbility (2008) states that where necessary AA1000AS can be used together with ISAE3000.

${ }^{23}$ We find 24 (40\%) firms do not make a reference to any assurance standard, 31 (52\%) follow either AA1000AS or ISAE3000 standard, and 5 (8\%) use both AA1000AS and ISAE3000.
} 
Consistent with our earlier findings, SUSCOM is negative and significant at $\mathrm{p}<0.05$ (Model 6.1 and 6.2). When we use assurance standard (SRAStd) as the dependent, we find ACEXP is positive and significant at $\mathrm{p}<0.01$ and ACMEET is positive and significant at $\mathrm{p}<0.01$ with SRA (Model 6.4). BODSIZE is positive and significant at $\mathrm{p}<0.05$ (Model 6.3) and SUSCOM is negative but insignificant (Models 6.3 and 6.4). Overall the results in Table 6 remain qualitatively similar and provide evidence of audit committees having an incremental effect, additional to that of the boards of directors and sustainability committees, on assurance type and standard.

Our results show that audit committees composed of independent members are associated with use of a Big 4 audit firm for SRA. Also, our results show that in the UK where there is no single benchmark against which sustainability reporting can be assessed, it appears that audit committees with expertise, independence and diligence are more likely to mitigate concerns about the ad hoc 'pick and mix' (O'Dwyer and Owen, 2005; Smith et al., 2011; Perego and Kolk, 2012) in SRA and to improve the oversight of the SRA process.

\section{SUMMARY AND CONCLUSION}

Recognising calls for more research on sustainability assurance and governance (Cohen and Simnett, 2015; Peters and Romi, 2015; Trotman and Trotman, 2015; Farooq and de Villiers, 2017), this paper addresses the impact of audit committees on voluntary SRA. Specifically, we test whether audit committees have a contribution additional to that of the boards of directors and the existence of sustainability committees on sustainability reporting assurance. Using a sample of companies listed in the UK FTSE350 in 2012, we find support for our hypothesis which indicates that they add credibility to sustainability reporting.

Our paper has a few limitations. The findings are restricted to UK FTSE350 companies in 2012 therefore a longitudinal study examining audit committee effects on SRA over time and in the context of specific corporate governance reforms would be useful. Future research 
can also supplement our study by conducting interviews with audit committee members and provide insights into the role of audit committees relating to SRA within particular organizational and institutional settings. Also, comparative studies focusing on different legal jurisdictions have the potential to shed more light on the effect of institutional and legal environment on SRA. Furthermore, our evidence suggests that further research examining the interaction between and roles of different agents involved in sustainability issues (Arena et al., 2018), in particular between audit committees, internal auditors, external auditors and management (Zaman and Sarens, 2013; Trotman and Trotman, 2015), and the consequences of the interaction and interdependencies between them on accountability to stakeholders is likely to be fruitful.

Our paper is likely to be of interest to regulators and practitioners. Recognising stakeholder and regulatory concerns about reliability of non-financial information and calls for audit committees to take on a wider remit, we explore the association between audit committees and SRA. A key contribution of our paper to the literature is showing that audit committees have an incremental contribution, i.e. additional to that of board of directors and the existence of sustainability committees, on SRA. Our findings suggest that rather than substituting for governance mechanisms audit committees play a complementary role and add credibility to sustainability reporting. 


\section{REFERENCES}

Abbott, L. J., Parker, S., \& Peters, G. F. (2004). Audit committee characteristics and restatements. Auditing: A Journal of Practice $\mathcal{E}$ Theory, 23(1), 69-87.

Abbott, L. J., Daugherty, B., Parker, S., \& Peters, G. F. (2015). Internal audit quality and financial reporting quality: The joint importance of independence and competence. Journal of Accounting Research, 54(1), 3-40.

AccountAbility (2008). Introduction to the revised AA1000 Assurance Standards and the AA1000 AccountAbility Principles Standard 2008, London, AccountAbility.

Al-Najjar, B. (2011). The determinants of audit committee independence and activity: evidence from the UK. International Journal of Auditing, 15(2), 191-203.

Al-Shaer, H. \& Zaman, M. (2016). Board gender diversity and sustainability reporting quality. Journal of Contemporary Accounting \& Economics, 12(3), 210-222.

Al-Shaer, H. Salama, A., \& Toms, S. (2017). Audit committees and financial reporting quality: evidence from UK environmental accounting disclosures. Journal of Applied Accounting Research, 18(1), 2-21.

Amran, A., Lee, S. P., \& Devi, S. S. (2014). The influence of governance structure and strategic corporate social responsibility toward sustainability reporting quality. Business Strategy and the Environment, 23(4), 217-235.

Arena, M., Azzone, G., \& Mapelli, F. (2018). What drives the evolution of Corporate Social Responsibility strategies? An institutional logics perspective. Journal of Cleaner Production, 171(Supplement C), 345-355.

Armstrong, C. S., Guay, W. R. \& Weber, J. P. (2010). The role of information and financial reporting in corporate governance and debt contracting. Journal of Accounting and Economics, 50(1), 179-234.

Beasley, M. S. (1996). An empirical analysis of the relation between the board of director composition and financial statement fraud. The Accounting Review, 71(1), 443-465.

Beasley, M. S., Carcello, J. V., Hermanson, D. R., \& Neal, T. L. (2009). The Audit committee oversight process, Contemporary Accounting Research, 26(1), 65-122.

Beattie, V., Fearnley, S., \& Hines, T. (2014). Boundary spanning and gatekeeping roles of UK audit committees. Accounting and Business Research, 44(3), 315-343.-

Bedard, J., \& Gendron, Y. (2010). Strengthening the financial reporting system: Can audit committees deliver? International Journal of Auditing, 14(2), 174-210.

Ben-Amar, W., \& Mcllkenny, P. (2015). Board effectiveness and the voluntary disclosure of climate change information. Business Strategy and the Environment, 24(8), 704-719.

Ben-Amar, W., Chang, M., \& Mcllkenny, P. (2017). Board gender diversity and corporate response to sustainability initiatives: evidence from the Carbon Disclosure Project. Journal of Business Ethics, 142(2), 369-383.

Bhimani, A., \& Soonawalla, K. (2005). From conformance to performance: The corporate responsibilities continuum. Journal of Accounting and Public Policy, 24(3), 165-174.

Birkey, R. N., Michelon, G., Patten, D. M., \& Sankara, J. (2016). Does assurance on CSR reporting enhance environmental reputation? An examination in the US context. Accounting Forum, 40(3), 143-152.

Casey, R. J., \& Grenier, J. H. (2014). Understanding and contributing to the enigma of corporate social responsibility (CSR) assurance in the United States. Auditing: A Journal of Practice \& Theory, 34(1), 97-130.

Carcello, J., Hermanson, D., \& Ye, Z. (2011). Corporate governance research in accounting and auditing: Insights, practice implications, and future research directions. Auditing: A Journal of Practice \& Theory, 30 (3): 1-31.

Chan, M. C., Watson, J., \& Woodliff, D. (2014). Corporate governance quality and CSR disclosures. Journal of Business Ethics, 125(1), 59-73. 
Cheng, M., Green, W., \& Ko, J. (2012). The impact of sustainability assurance and company strategy on investors' decisions. Australian Accounting Review, 2(1), 58-74.

Clarkson, P. M., Li, Y., Pinnuck, M. \& Richardson, G. (2015a). The valuation relevance of greenhouse gas emissions under the European Union Carbon Emissions Trading Scheme. European Accounting Review, 24(3), 551-580.

Clarkson, P. M., Li, Y., Richardson, G., \& Tsang, A. (2015b). Voluntary external assurance of corporate social responsibility reports and the Dow Jones Sustainability Index Membership: International evidence. Working Paper. SSRN.

Cohen, J., Krishnamoorthy, G., \& Wright, A. (2004). The corporate governance mosaic and financial reporting quality, Journal of Accounting Literature, 23(1), 87-152.

Cohen, J., \& Simnett, R. (2015). CSR and assurance services: A research agenda. Auditing: A Journal of Practice $\mathcal{E}$ Theory, 34(1), 59-74.

Collier, P., \& Zaman, M. (2005). Convergence in European corporate governance: The audit committee concept. Corporate Governance: An International Review, 13(6), 753-768.

CorporateRegister.com. (2008). Assure View: The CSR assurance statement report. CorporateRegister.com Limited, London.

Darnall, N., Seol, I., \& Sarkis, J. (2009). Perceived stakeholder influences and organizations' use of environmental audits. Accounting, Organizations and Society, 34(2), 170-187.

DEFRA. (2013). Environmental Reporting Guidelines. London: Department for Environment Food and Rural Affairs.

De Villiers, C., Naiker, V., \& Van Staden, C. J. (2011). The effect of board characteristics on firm environmental performance. Journal of Management, 37(1), 1636-1663.

Dutta, S., Lawson, R., \& Marcinko, D. (2012). Paradigms for sustainable development: Implications of management theory. Corporate Social Responsibility and Environmental Management, 19(1), 1-10.

Erkens, D. H., \& Bonner, S. E. (2012). The role of firm status in appointments of accounting financial experts to audit committees. The Accounting Review, 88(1), 107-136.

EY. (2010). Regulatory change is driving audit committee agendas. Insights for North American Audit Committee Members Newsletter.

EY. (2014). The audit committee leadership summit, ViewPoints, Issue 25.

Farooq, M. B., \& de Villiers, C. (2017). The market for sustainability assurance services: A comprehensive literature review and future avenues for research. Pacific Accounting Review, 29(1), 79-106.

Ferguson, A. \& Pündrich, G. (2015). Does industry specialist assurance of non-financial information matter to investors?, Auditing: A Journal of Practice $\mathcal{E}$ Theory, 34(2), 121-146.

FERMA. (2014). Audit and Risk Committees: Guidance for Boards. ECIAA.

FRC. (2015). The UK Corporate Governance Code. London: Financial Reporting Council.

Galbreath, J. (2010). Corporate governance practices that address climate change: An exploratory study. Business Strategy and the Environment, 19(5), 335-350.

GRI. (2013). The external assurance of sustainability reporting. Amsterdam, the Netherlands: Global Reporting Initiative.

Goh, B. (2009). Audit committees, boards of directors, and remediation of material weaknesses in internal control. Contemporary Accounting Research, 26(2), 549-579.

Green, W. \& Taylor, S. (2013). Factors that influence perceptions of greenhouse gas assurance provider quality. International Journal of Auditing, 17(3), 288-307.

Hay, D., Knechel, W. R. \& Ling, H. (2008), Evidence on the impact of internal control and corporate governance on audit fees. International Journal of Auditing, 12: 9-24.

Helfaya, A., \& Moussa, T. (2017). Do Board's Corporate Social Responsibility Strategy and Orientation Influence Environmental Sustainability Disclosure? UK Evidence. Business Strategy and the Environment, forthcoming. 
Hillman, A. J., \& Dalziel, T. (2003). Boards of directors and firm performance: Integrating agency and resource dependence perspectives. Academy of Management Review, 28(3), 383-396.

Hillman, A. J., Withers, M. C., \& Collins, B. J. (2009). Resource dependence theory: A review. Journal of Management, 35(6), 1404-1427.

ICAA. (2014). Guide for Audit Committees in Australia and New Zealand. Institute of Chartered Accountants Australia: Sydney.

ICAEW. (1999). Turnbull Report - Internal Control Guidance for Directors on the Combined Code. Institute of Chartered Accountants in England and Wales: London.

International Auditing and Assurance Standards Board. (2011). ISAE 3000 (Revised), Assurance engagements other than audits or reviews of historical financial information.

Jensen, M. C., \& Meckling, W. H. (1976). Theory of the firm: Managerial behavior, agency costs and ownership structure. Journal of Financial Economics, 3(4), 305-360.

Jizi, M. (2017). The Influence of Board Composition on Sustainable Development Disclosure. Business Strategy and the Environment, forthcoming.

Jones, M. J. \& Solomon, J. F. (2010). Social and environmental report assurance: some interview evidence. Accounting Forum, 34(1), 20-31.

Junior, R.M., Best, P.J., \& Cotter, J. (2014). Sustainability reporting and assurance: a historical analysis on a world-wide phenomenon. Journal of Business Ethics, 120(1), 1-11.

Hodge, K., Subramaniam, N., \& Stewart, J. (2009). Assurance of sustainability reports: Impact on report users' confidence and perceptions of information credibility. Australian Accounting Review, 19(3), 178-194.

Klein, A. (2002). Audit committee, board of director characteristics, and earnings management. Journal of Accounting and Economics, 33(3), 375-400.

Knechel, W. R. \& Willekens, M. (2006). The role of risk management and governance in determining audit demand. Journal of Business Finance \& Accounting, 33(9\&10), 13441367.

KPMG. (2014). Global Audit Committee Survey, KPMG Audit Committee Institute.

Lansen-Rogers, J., \& Oelschlaegel, J. (2005). Assurance Standards Briefing: AA1000 Assurance Standard \& ISAE3000. Amsterdam: AccountAbility and KPMG Sustainability.

Lim, S., Matolcsy, Z. \& Chow, D. (2007). The association between board composition and different types of voluntary disclosure. European Accounting Review, 16(3), 555-583.

Li, J., Mangena, M., \& Pike, R. (2012). The effect of audit committee characteristics on intellectual capital disclosure. British Accounting Review, 44(2), 98-110.

Mallin, C. A., \& Michelon, G. (2011). Board reputation attributes and corporate social performance: An empirical investigation of the US best corporate citizens. Accounting and Business Research, 41(2), 119-144.

Mangena, M. \& Pike, R. (2005). The effect of audit committee shareholding, financial expertise and size on interim financial disclosures. Accounting and Business Research, 35, 327-349.

Markarian, G., \& Parbonetti, A. (2007). Firm complexity and board of director composition. Corporate governance: an international review, 15(6), 1224-1243.

Martinov-Bennie, N., Dominic, S. B. \& Tweedie, D. (2015). An investigation into the roles, characteristics, expectations and evaluation practices of audit committees. Managerial Auditing Journal, 30(8/9), 727-755.

Mat Zain, M., Zaman, M., \& Mohamed, Z. (2015). The effect of internal audit function quality and internal audit contribution to external audit fees. International Journal of Auditing, 19(3), 134-147.

Michelon, G., \& Parbonetti, A. (2012). The effect of corporate governance on sustainability disclosure. Journal of Management \& Governance, 16(3), 477-509. 
Mock, T. J., Rao, S. S. \& Srivastava, R. P. (2013). The development of worldwide sustainability reporting assurance. Australian Accounting Review, 23(4), 280-294.

Moroney, R., \& Trotman, K. T. (2016). Differences in auditors' materiality assessments when auditing financial and sustainability reports. Contemporary Accounting Research, 33(2), 551-575.

Moroney, R., Windsor, C. \& Ting Aw, Y. (2012). Evidence of assurance enhancing the quality of voluntary environmental disclosures: An empirical analysis. Accounting $\mathcal{E}$ Finance, 52(3), 903-939.

O'Dwyer, B. (2011). The case of sustainability assurance: Constructing a new assurance service. Contemporary Accounting Research, 28(4), 1230-1266.

O’Dwyer, B., Owen, D., \& Unerman, J. (2011). Seeking legitimacy for new assurance forms: The case of assurance on sustainability reporting. Accounting, Organizations and Society, 36(1), 31-52.

O'Dwyer, B., \& Owen, D. (2005). Assurance statement practice in environmental, social and sustainability reporting: A critical evaluation. British Accounting Review, 37(2), 205-229.

O'Dwyer, B. (2003). Conceptions of corporate social responsibility: the nature of managerial capture. Accounting, Auditing \& Accountability Journal, 16(4), 523-557.

Ortiz-de-Mandojana, N., \& Aragon-Correa, J. A. (2015). Boards and sustainability: the contingent influence of director interlocks on corporate environmental performance. Business Strategy and the Environment, 24(6), 499-517.

Perego, P., \& Kolk, A. (2012). Multinationals' accountability on sustainability: The evolution of third-party assurance of sustainability reports. Journal of Business Ethics, 110(2), 173190.

Peters, G. F., \& Romi, A. M. (2015). The association between sustainability governance characteristics and the assurance of corporate sustainability reports. Auditing: A Journal of Practice \& Theory, 34(1), 163-198.

Pflugrath, G., Roebuck, P., \& Simnett, R. (2011). Impact of assurance and assurer's professional affiliation on financial analysts' assessment of credibility of corporate social responsibility information. Auditing: A Journal of Practice $\mathcal{E}$ Theory, 30(3), 239-254.

Pomeroy, B., \& Thornton, D. B. (2008). Meta-analysis and the accounting literature: The case of audit committee independence and financial reporting quality. European Accounting Review, 17(2), 305-330.

Post, C., Rahman, N., \& Rubow, E. (2011). Green governance: Boards of directors' composition and environmental corporate social responsibility. Business $\mathcal{E}$ Society, 50(1), 189-223.

Ruhnke, K., \& Gabriel, A. (2013). Determinants of voluntary assurance on sustainability reports: an empirical analysis. Journal of Business Economics, 83(9), 1063-1091.

Rodrigue, M., Magnan, M., \& Cho, C. H. (2013). Is environmental governance substantive or symbolic? An empirical investigation. Journal of Business Ethics, 114(1), 107-129.

Rowe, A. L., Nowak, M., Quaddus, M., \& Naude, M. (2014). Stakeholder engagement and sustainable corporate community investment. Business Strategy and the Environment, 23(7), 461-474.

Salleh, Z., \& Stewart, J. (2012). The role of the audit committee in resolving auditor-client disagreements: a Malaysian study. Accounting, Auditing $\mathcal{E}$ Accountability Journal, 25(8), 1340-1372.

Sarens, G, Christopher, J. \& Zaman, M. (2013). Nature and extent of informal interactions between internal audit functions and audit committees: Survey of Australian chief audit executives. Australian Accounting Review, 23(4), 307-329.

Shaukat, A., Qiu, Y., \& Trojanowski, G. (2016). Board attributes, corporate social responsibility strategy, and corporate environmental and social performance. Journal of Business Ethics, 135(3), 569-585. 
Sierra, L., Zorio, A. \& García-Benau, M.A. (2013). Sustainable development and assurance of corporate social responsibility reports published by IBEX-35 companies. Corporate Social Responsibility and Environmental Management, 20(6), 359-370.

Simnett, R. (2012). Assurance of sustainability reports: Revision of ISAE3000 and associated research opportunities. Sustainability Accounting, Management and Policy Journal, 3(1), 89-98.

Simnett, R., Vanstraelen, A., \& Chua, W.F. (2009a). Assurance on sustainability reports: An international comparison. The Accounting Review, 84(3), 937-967.

Simnett, R., Nugent, M., \& Huggins, A.L. (2009b). Developing an international assurance standard on greenhouse gas statements. Accounting Horizons, 23(4), 347-363.

Smith, J., Haniffa, R. \& Fairbrass, J. (2011). A conceptual framework for investigating 'capture' in corporate sustainability reporting assurance. Journal of Business Ethics, 99(3), 425439.

Trotman, A. J., \& Trotman, K. T. (2015). Internal audit's role in GHG emissions and energy reporting: Evidence from audit committees, senior accountants, and internal auditors. Auditing: A Journal of Practice \& Theory, 34(1), 199-230.

Turley, S. \& Zaman, M. (2004). The corporate governance effects of audit committees. Journal of Management and Governance, 8, 305-32.

Turley, S., \& Zaman, M. (2007). Audit committee effectiveness: informal processes and behavioural effects', Accounting, Auditing \& Accountability Journal, 20(5), 765-788.

Xie, S., \& Hayase, K. (2007). Corporate environmental performance evaluation: a measurement model and a new concept. Business Strategy and the Environment, 16(2), 148-168.

Yadav, P. L., Han, S. H., \& Rho, J. J. (2016). Impact of environmental performance on firm value for sustainable investment: evidence from large US firms. Business Strategy and the Environment, 25(6), 402-420.

Young, S., \& Marais, M. (2012). A multi-level perspective of CSR reporting: The implications of national institutions and industry risk characteristics. Corporate Governance: An International Review, 20(5), 432-450.

Zaman, M. \& Sarens, G. (2013). Informal interactions between audit committees and internal audit functions: exploratory evidence and directions for future research. Managerial Auditing Journal, 28(6), 495-515.

Zaman, M., Hudaib, M., \& Haniffa, R. (2011). Corporate governance quality, audit fees and non-audit services fees. Journal of Business Finance \& Accounting, 38(1-2), 165-197.

Zhang, J.Q., Zhu, H., \& Ding, H. (2013). Board composition and corporate social responsibility: An empirical investigation in the post Sarbanes-Oxley era. Journal of Business Ethics, 114(3): 381-392.

Zhang, Y., Zhou, J. \& N. Zhou, N. (2007). Audit committee quality, auditor independence and internal control weaknesses, Journal of Accounting and Public Policy, 26: 300-327. 
Table 1: Descriptive Statistics

\begin{tabular}{|c|c|c|c|c|c|c|c|c|c|c|c|c|c|}
\hline \\
\hline Panel A: All firms & $\mathbf{N}$ & SRA & ACSIZE & ACIND & ACEXP & ACMEET & SUSCOM & BODSIZE & BODIND & BODMEET & SIZE & ROA & LEV \\
\hline Mean & 333 & 0.174 & 3.922 & 0.781 & 0.258 & 4.158 & 0.36 & 9.336 & 0.51 & 8.187 & $1,149,379$ & 0.079 & 0.189 \\
\hline Median & 333 & 0 & 4 & 1 & 0.25 & 4 & 0 & 9 & 0.571 & 8 & $320,636.50$ & 0.071 & 0.153 \\
\hline Std.Dev & 333 & 0.379 & 0.975 & 0.076 & 0.212 & 1.715 & 0.48 & 2.656 & 0.275 & 2.723 & $4,737,005$ & 0.124 & 0.168 \\
\hline Skewness & 333 & 1.718 & 0.484 & -4.168 & 0.397 & 1.717 & 0.581 & 0.533 & -0.7 & 0.957 & -0.941 & -0.191 & 0.835 \\
\hline Kurtosis & 333 & 3.952 & 3.761 & 19.123 & 2.532 & 7.238 & 1.338 & 3.069 & 2.706 & 4.529 & 3.816 & 4.304 & 3.161 \\
\hline Maximum & 333 & 1 & 7 & 1 & 1 & 15 & 1 & 21 & 1 & 20 & $81,300,000$ & 1.75 & 0.912 \\
\hline Minimum & 333 & 0 & 2 & 0 & 0 & 1 & 0 & 4 & 0 & 2 & 100,000 & -0.325 & 0 \\
\hline \multicolumn{14}{|l|}{ Panel B: Means: Industry } \\
\hline Oil \& Gas & 18 & 0.333 & 3.833 & 1 & 0.194 & 4.222 & 0.277 & 10.438 & 0.531 & 8.125 & $26,835,110$ & 0.076 & 0.14 \\
\hline Basic Materials & 29 & 0.482 & 3.655 & 0.991 & 0.209 & 4.172 & 0.482 & 10.125 & 0.562 & 7.75 & $18,543,880$ & 0.052 & 0.224 \\
\hline Industrials & 66 & 0.166 & 3.954 & 0.911 & 0.301 & 4.015 & 0.424 & 9.279 & 0.508 & 9.016 & $2,619,386$ & 0.098 & 0.2 \\
\hline Consumer Goods & 24 & 0.166 & 3.666 & 0.971 & 0.322 & 3.916 & 0.625 & 9.565 & 0.476 & 8.304 & $8,373,834$ & 0.095 & 0.191 \\
\hline Health Care & 8 & 0.125 & 4.25 & 1 & 0.236 & 4.875 & 0.5 & 10.625 & 0.568 & 9.75 & $10,224,953$ & 0.096 & 0.249 \\
\hline Consumer Svs & 57 & 0.123 & 3.824 & 0.964 & 0.296 & 4 & 0.315 & 9.545 & 0.463 & 8.364 & $3,913,217$ & 0.113 & 0.226 \\
\hline Telecom & 9 & 0.222 & 3.888 & 1 & 0.413 & 4.111 & 0.555 & 9.833 & 0.418 & 8 & $21,363,163$ & 0.045 & 0.356 \\
\hline Utilities & 7 & 0.286 & 4 & 1 & 0.257 & 4.428 & 0.571 & 10.143 & 0.541 & 8.286 & $16,120,271$ & 0.057 & 0.418 \\
\hline Financials & 100 & 0.009 & 4.107 & 0.978 & 0.21 & 4.264 & 0.21 & 8.902 & 0.565 & 7.451 & $64,723,160$ & 0.047 & 0.157 \\
\hline Technology & 15 & 0.133 & 3.733 & 0.951 & 0.243 & 4.466 & 0.4 & 7.909 & 0.427 & 9.091 & 793,397 & 0.083 & 0.082 \\
\hline \multicolumn{14}{|l|}{ Panel C: Means: Subsample } \\
\hline$S R A=1$ & 60 & - & 4.052 & 0.997 & 0.315 & 4.707 & 0.310 & 10.517 & 0.539 & 8.448 & 11.293 & 0.060 & 0.242 \\
\hline$S R A=0$ & 273 & - & 3.905 & 0.982 & 0.242 & 4.047 & 0.371 & 9.097 & 0.501 & 8.151 & 11.241 & 0.077 & 0.177 \\
\hline t-test & & - & -1.055 & -1.629 & $-2.465^{\star \star *}$ & $-2.810^{* * *}$ & 0.871 & $-3.835^{\star * *}$ & -0.948 & -0.774 & -0.121 & 1.513 & $-2.806^{* * *}$ \\
\hline Mann-Whitney value & & - & -1.249 & -1.467 & $-2.022^{* *}$ & $-3.007^{* * *}$ & 0.872 & $-3.593^{* * *}$ & -1.212 & -0.787 & 0.119 & 1.856 & $-3.485^{* * *}$ \\
\hline SUSCOM=1 & 120 & 0.150 & 3.925 & 0.991 & 0.289 & 4.550 & - & 10.025 & 0.498 & 8.622 & 11.175 & 0.073 & 0.223 \\
\hline SUSCOM=0 & 213 & 0.187 & 3.934 & 0.981 & 0.238 & 3.962 & - & 8.946 & 0.512 & 7.971 & 11.283 & 0.076 & 0.168 \\
\hline t-test & & 0.871 & 0.085 & $-1.503^{*}$ & $-2.155^{* *}$ & $-2.964^{* * *}$ & - & $-3.725^{\star \star *}$ & 0.467 & $-2.165^{* *}$ & 0.277 & 0.084 & $-2.985^{* * *}$ \\
\hline Mann-Whitney value & & 0.872 & 0.410 & -1.417 & $-1.956^{*}$ & $-2.631^{* * *}$ & - & $-4.134^{* * *}$ & -0.061 & $-2.701^{* * *}$ & 0.222 & 0.957 & $-2.998^{* * *}$ \\
\hline
\end{tabular}

Notes: $\mathrm{SRA}=$ if sustainability report is externally assured $=1,0$ otherwise; $\mathrm{ACSIZE}=$ number of audit committee members; $\mathrm{ACIND}=$ proportion of audit committee members who are independent; $\mathrm{ACEXP}=$ proportion of audit committee members with financial expertise; of board meetings held during the year; SIZE= total assets ('000 GBP); ROA= return on asset; $\mathrm{LEV}=$ total debt to total asset; $\mathrm{IND}=$ industry dummy variable. 
Table 2: Correlation Matrix

\begin{tabular}{|c|c|c|c|c|c|c|c|c|c|c|c|c|}
\hline & SRA & ACSIZE & ACIND & ACEXP & ACMEET & SUSCOM & BODSIZE & BODIND & BODMEET & SIZE & ROA & LEV \\
\hline SRA & 1.000 & & & & & & & & & & & \\
\hline ACSIZE & 0.084 & 1.000 & & & & & & & & & & \\
\hline ACIND & 0.085 & -0.007 & 1.000 & & & & & & & & & \\
\hline ACEXP & 0.083 & -0.053 & -0.037 & 1.000 & & & & & & & & \\
\hline ACMEET & $0.158^{* * *}$ & $0.116^{* *}$ & -0.005 & $0.153^{* * *}$ & 1.000 & & & & & & & \\
\hline SUSCOM & -0.054 & -0.039 & 0.080 & $0.119^{* *}$ & $0.142^{* *}$ & 1.000 & & & & & & \\
\hline BODSIZE & $0.202^{* * *}$ & $0.207^{* * *}$ & -0.004 & $0.121^{* *}$ & $0.321^{\text {*** }}$ & $0.224^{* * *}$ & 1.000 & & & & & \\
\hline BODIND & 0.066 & $0.123^{* *}$ & 0.030 & 0.002 & $0.120^{* *}$ & -0.017 & 0.082 & 1.000 & & & & \\
\hline BODMEET & 0.047 & 0.029 & 0.000 & $0.135^{\star * *}$ & $0.168^{* * *}$ & $0.161^{* *}$ & $0.166^{* * * *}$ & -0.018 & 1.000 & & & \\
\hline SIZE & -0.036 & -0.02 & $0.121^{* *}$ & -0.054 & -0.044 & -0.015 & $-0.237^{* * *}$ & -0.079 & -0.019 & 1.000 & & \\
\hline ROA & $-0.105^{*}$ & $-0.103^{*}$ & 0.057 & $0.133^{* *}$ & -0.036 & -0.051 & -0.098 & -0.074 & 0.01 & $-0.193^{* * *}$ & 1.000 & \\
\hline LEV & $0.176^{* *}$ & 0.066 & 0.059 & 0.101 & -0.013 & $0.172^{* * *}$ & $0.106^{*}$ & 0.011 & 0.056 & 0.043 & $-0.106^{*}$ & 1.000 \\
\hline
\end{tabular}

Spearman two tailed, $* * * * * * *=0.1,0.05,0.01$ level

Notes: $\mathrm{SRA}=$ if sustainability report is externally assured=1, 0 otherwise; ACSIZE=number of audit committee members; $\mathrm{ACIND=proportion} \mathrm{of} \mathrm{audit} \mathrm{committee}$ members who are independent; ACEXP=proportion of audit committee members with financial expertise; ACMEET= number of audit committee meetings held during the year; SUSCOM= if a sustainability committee exists =1, otherwise 0 ; BODSIZE=number of directors on the board; BODIND= proportion of independent directors on the board; BODMEET= number of board meetings held during the year SIZE= natural log of total assets; ROA= return on asset; $\mathrm{LEV}=$ total debt to total asset; IND= industry dummy variable. 
Table 3: ACs and Credibility of Sustainability Reports

\begin{tabular}{|l|c|c|c|c|}
\hline$D V=S R A$ & \multicolumn{2}{|c|}{ All firms } & Small firms & Large firms \\
\hline & Model 3.1 & Model 3.2 & Model 3.3 & Model 3.4 \\
\hline ACSIZE & & 0.137 & 0.455 & -0.031 \\
\hline ACIND & & $8.157^{* * *}$ & $4.742^{* *}$ & $0.689^{* *}$ \\
\hline ACEXP & & $1.432^{*}$ & 0.057 & $0.249^{*}$ \\
\hline ACMEET & & $0.251^{* *}$ & $0.452^{* *}$ & $0.325^{* *}$ \\
\hline SUSCOM & $-0.758^{*}$ & $-1.142^{* * *}$ & $-2.328^{* * *}$ & 0.356 \\
\hline BODSIZE & $1.257^{* * *}$ & $0.214^{* * *}$ & $0.244^{*}$ & 1.03 \\
\hline BODIND & 1.471 & -0.158 & -3.2 & 0.646 \\
\hline BODMEET & 1.02 & 0.009 & 0.113 & -0.033 \\
\hline SIZE & 1.037 & 0.026 & $0.214^{*}$ & 0.025 \\
\hline ROA & 0.191 & -3.834 & 0.76 & $-8.565^{* *}$ \\
\hline LEV & $8.320^{* * *}$ & $2.689^{* * *}$ & 1.682 & $3.072^{* *}$ \\
\hline IND & Included & Included & Included & Included \\
\hline cons & $-4.829^{* * *}$ & $-17.854^{* * *}$ & $-20.627^{* * *}$ & $19.151^{* *}$ \\
\hline Pseudo R 2 & 0.147 & 0.225 & 0.346 & 0.284 \\
\hline Wald Chi2 & 40.60 & 49.15 & 37.40 & 270.83 \\
\hline Prob >Chi2 & 0.000 & 0.000 & 0.000 & 0.000 \\
\hline Average VIF & 3.53 & 2.97 & 2.62 & 4.98 \\
\hline
\end{tabular}

$*, * *, * * *=0.1,0.05,0.01$ level

Notes: SRA=if sustainability report is externally assured=1, 0 otherwise; ACSIZE=number of audit committee members; ACIND=proportion of audit committee members who are independent; $\mathrm{ACEXP}=$ proportion of audit committee members with financial expertise; ACMEET= number of audit committee meetings held during the year; $\mathrm{SUSCOM}=$ if a sustainability committee exists $=1$, otherwise 0 ; $\mathrm{BODSIZE}=$ number of directors on the board; $\mathrm{BODIND}=$ proportion of independent directors on the board; BODMEET = number of board meetings held during the year SIZE= natural log of total assets; $\mathrm{ROA}=$ return on asset; $\mathrm{LEV}=$ total debt to total asset; IND= industry dummy variable. 
Table 4: Credibility of Sustainability Reports: interaction effects

\begin{tabular}{|l|c|c|l|}
\hline $\boldsymbol{D} V$ SR $\boldsymbol{A}$ & Full Sample & Small firms & Large firms \\
\hline & Model 4.1 & Model 4.2 & Model 4.3 \\
\hline ACSIZE* SUSCOM & -0.247 & -0.458 & 1.851 \\
\hline ACIND* SUSCOM & $5.649^{* *}$ & $6.446^{* *}$ & 0.002 \\
\hline ACEXP* SUSCOM & $3.333^{*}$ & $4.563^{* *}$ & 5.540 \\
\hline ACMEET* SUSCOM & -0.205 & -0.231 & 2.631 \\
\hline ACSIZE & 0.248 & 0.379 & 0.835 \\
\hline ACIND & $9.376^{* *}$ & $10.970^{* *}$ & 0.034 \\
\hline ACEXP & 0.051 & 0.252 & 0.650 \\
\hline ACMEET & $0.355^{* *}$ & $0.407^{*}$ & $1.776^{* *}$ \\
\hline SUSCOM & $-5.873^{* * *}$ & $-6.790^{* * *}$ & 0.031 \\
\hline BODSIZE & $0.229^{* * *}$ & $0.320^{* * *}$ & 1.032 \\
\hline BODIND & -0.177 & -1.878 & 1.489 \\
\hline BODMEET & 0.015 & 0.088 & 0.864 \\
\hline SIZE & 0.011 & -0.067 & 0.616 \\
\hline ROA & -3.783 & -0.586 & 0.042 \\
\hline LEV & $2.694^{* * *}$ & $3.343^{* *}$ & 8.616 \\
\hline IND & Included & Included & Included \\
\hline Pseudo R & 0.242 & 0.337 & 0.303 \\
\hline Prob Chi2 & 0.000 & 0.000 & 0.000 \\
\hline Average VIF & 1.43 & 1.51 & 1.64 \\
\hline
\end{tabular}

${ }^{* * *} p<0.01,{ }^{* *} p<0.05,{ }^{*} p<0.1$, all models are tested using logit specification.

Notes: SRA=if sustainability report is externally assured=1, 0 otherwise; ACSIZE=number of audit committee members; $\mathrm{ACIND}=$ proportion of audit committee members who are independent; $\mathrm{ACEXP}=$ proportion of audit committee members with financial expertise; ACMEET= number of audit committee meetings held during the year; $\mathrm{SUSCOM}=$ if a sustainability committee exists $=1$, otherwise 0 ; $\mathrm{BODSIZE}=$ number of directors on the board; $\mathrm{BODIND}=$ proportion of independent directors on the board; BODMEET = number of board meetings held during the year SIZE= natural log of total assets; $\mathrm{ROA}=$ return on asset; $\mathrm{LEV}=$ total debt to total asset; $\mathrm{IND}=$ industry dummy variable. 
Table 5: Additional Analysis: Industry Effects

\begin{tabular}{|l|c|c|c|c|}
\hline \multicolumn{1}{|c|}{ DV= SRA } & \multicolumn{2}{c|}{ Non-Financial Firms Sample } & \multicolumn{2}{c|}{ Sustainability Sensitive Industries' } \\
\hline & Model 5.1 & Model 5.2 & Model 5.3 & Model 5.4 \\
\hline ACSIZE & & 0.151 & & 0.025 \\
\hline ACIND & & $12.328^{* *}$ & & $5.257^{* * *}$ \\
\hline ACEXP & & 0.388 & & 0.906 \\
\hline ACMEET & & $0.314^{* * *}$ & & $0.245^{* * *}$ \\
\hline SUSCOM & $-1.232^{* * *}$ & $-1.399^{* * *}$ & $-0.855^{* *}$ & $-1.061^{* * *}$ \\
\hline BODSIZE & $0.223^{* * *}$ & $0.246^{* * *}$ & $0.231^{* * *}$ & $0.221^{* * *}$ \\
\hline BODIND & 0.325 & -0.302 & 0.501 & 0.064 \\
\hline BODMEET & 0.022 & 0.025 & 0.001 & -0.003 \\
\hline SIZE & 0.041 & 0.051 & 0.03 & 0.021 \\
\hline ROA & -0.915 & -1.136 & $-3.881^{*}$ & $-4.564^{*}$ \\
\hline LEV & $2.449^{* *}$ & $3.122^{* *}$ & $1.891^{* *}$ & $2.232^{* *}$ \\
\hline Non-financial industries & Included & Included & & \\
\hline Sustainability-sensitive & & & Included & Included \\
\hline cons & $-4.362^{* * *}$ & $-18.276^{* * *}$ & $-3.853^{* * *}$ & $-14.715^{* * *}$ \\
\hline Pseudo R 2 & 0.135 & 0.222 & 0.122 & 0.182 \\
\hline Wald Chi2 & 30.38 & 42.25 & 35.01 & 44.98 \\
\hline Prob> Chi2 & 0.000 & 0.000 & 0.000 & 0.000 \\
\hline Average VIF & 1.09 & 1.13 & 1.96 & 1.75 \\
\hline
\end{tabular}

$* * *, * * *=0.1,0.05,0.01$ level

Notes: SRA=if sustainability report is externally assured=1, 0 otherwise; ACSIZE=number of audit committee members; ACIND=proportion of audit committee members who are independent; $\mathrm{ACEXP}=$ proportion of audit committee members with financial expertise; ACMEET= number of audit committee meetings held during the year; $\mathrm{SUSCOM}=$ if a sustainability committee exists $=1$, otherwise 0 ; $\mathrm{BODSIZE}=$ number of directors on the board; $\mathrm{BODIND}=$ proportion of independent directors on the board; BODMEET = number of board meetings held during the year; $\mathrm{SIZE}=$ natural $\log$ of total assets; $\mathrm{ROA}=$ return on asset; $\mathrm{LEV}=$ total debt to total asset; IND= industry dummy variable. 
Table 6: Additional Analysis: SRA Type and Standard

\begin{tabular}{|l|c|c|c|c|}
\hline DV & \multicolumn{2}{|c|}{ SRAType } & \multicolumn{2}{c|}{ SRAStd } \\
\hline & Model 6.1 & Model 6.2 & Model 6.3 & Model 6.4 \\
\hline ACSIZE & & -0.470 & & -0.117 \\
\hline ACIND & & $5.997^{* * *}$ & & 3.317 \\
\hline ACEXP & & 0.217 & & $0.770^{* * *}$ \\
\hline ACMEET & & 0.018 & & $0.277^{* *}$ \\
\hline SUSCOM & $-1.218^{* *}$ & $-2.259^{* * *}$ & -0.037 & -0.042 \\
\hline BODSIZE & $0.077^{*}$ & $0.244^{* *}$ & $0.215^{* *}$ & 0.117 \\
\hline BODIND & 0.148 & $-1.761^{*}$ & 0.713 & 0.916 \\
\hline BODMEET & 0.044 & 0.025 & $-0.235^{*}$ & $-0.294^{*}$ \\
\hline SIZE & 0.047 & $0.157^{* *}$ & 0.101 & $-0.199^{* *}$ \\
\hline ROA & -0.561 & -3.709 & -0.784 & $-5.560^{*}$ \\
\hline LEV & -0.104 & $-4.896^{*}$ & -0.767 & -1.023 \\
\hline IND & Included & Included & Included & Included \\
\hline Pseudo R 2 & 0.205 & 0.372 & 0.251 & 0.433 \\
\hline LR Chi2 & 23.66 & 39.12 & 25.46 & 39.87 \\
\hline Prob> Chi2 & 0.002 & 0.000 & 0.001 & 0.000 \\
\hline Average VIF & 1.78 & 2.26 & 1.78 & 2.26 \\
\hline
\end{tabular}

$* * * * * *=0.1,0.05,0.01$ level

Notes: SRAType $=1$ if sustainability report is assured by a non-accounting firm, 2 if assured a non-Big Four accounting firm, and 3 if assurer is a Big Four firm; SRAStd =0 if sustainability reports are assured but no assurance standard is specified, 1 if either AA1000AS or ISAE3000 is used, and 2 if both standards are used for SRA; ACSIZE=number of audit committee members; ACIND=proportion of audit committee members who are independent; $\mathrm{ACEXP}=$ proportion of audit committee members with financial expertise; ACMEET= number of audit committee meetings held during the year; SUSCOM= if a sustainability committee exists =1, otherwise 0; BODSIZE=number of directors on the board; $\mathrm{BODIND}=$ proportion of independent directors on the board; BODMEET = number of board meetings held during the year $\mathrm{SIZE}=$ natural log of total assets; $\mathrm{ROA}=$ return on asset; $\mathrm{LEV}=$ total debt to total asset; IND= industry dummy variable. 